\title{
Editors' Overview \\ Perspectives on Teaching Social Responsibility to Students in Science and Engineering
}

\author{
Henk Zandvoort • Tom Børsen • Michael Deneke • \\ Stephanie J. Bird
}

Received: 14 October 2013/Accepted: 30 October 2013/Published online: 26 November 2013

(C) Springer Science+Business Media Dordrecht 2013

\begin{abstract}
Global society is facing formidable current and future problems that threaten the prospects for justice and peace, sustainability, and the well-being of humanity both now and in the future. Many of these problems are related to science and technology and to how they function in the world. If the social responsibility of scientists and engineers implies a duty to safeguard or promote a peaceful, just and sustainable world society, then science and engineering education should empower students to fulfil this responsibility. The contributions to this special issue present European examples of teaching social responsibility to students in science and engineering, and provide examples and discussion of how this teaching can be promoted, and of obstacles that are encountered. Speaking generally, education aimed at preparing future scientists and engineers for social responsibility is presently very limited and seemingly insufficient in view of the enormous ethical and social problems that are associated with current science and technology. Although many social, political and professional organisations have expressed the need for the provision of teaching for social responsibility, important and persistent barriers
\end{abstract}

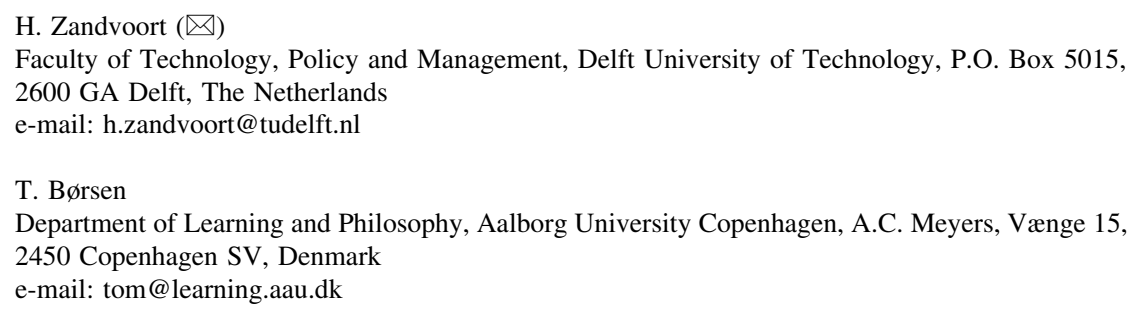

\section{Deneke}

Irenenstr. 5, 64293 Darmstadt, Germany

e-mail: m_deneke@t-online.de

\section{S. J. Bird}

Science and Engineering Ethics, P.O. Box 2007, Wrentham, MA 02093, USA

e-mail: sjbird@mit.edu 
stand in the way of its sustained development. What is needed are both bottom-up teaching initiatives from individuals or groups of academic teachers, and top-down support to secure appropriate embedding in the university. Often the latter is lacking or inadequate. Educational policies at the national or international level, such as the Bologna agreements in Europe, can be an opportunity for introducing teaching for social responsibility. However, frequently no or only limited positive effect of such policies can be discerned. Existing accreditation and evaluation mechanisms do not guarantee appropriate attention to teaching for social responsibility, because, in their current form, they provide no guarantee that the curricula pay sufficient attention to teaching goals that are desirable for society as a whole.

Keywords Social responsibility $\cdot$ Science education $\cdot$ Engineering education - University education · Engineering ethics · Research ethics · Responsible conduct of research $\cdot$ RCR $\cdot$ Sustainability

\section{Introduction}

While knowledge and technology produced by natural scientists, technologists and engineers can enhance human well-being, there are also actual and potential negative effects. In addition to the possibility of deliberate misuse, there is always the potential for (or reality of) unforeseen risks and unintended negative consequences such as pollution and the depletion of natural resources, which may in turn lead to social conflicts of various sorts. Students of science and engineering are usually unaware of the potential dilemmas that stem from this and that they are likely to face. It is a key task of science and engineering education to empower students to recognise and respond effectively to these dilemmas, although it is a task that often is unrecognized, unacknowledged and unaddressed. Nevertheless it is essential that they be so empowered if they are both to contribute effectively to the improvement of the social, legal and institutional context in which they work, and to secure a positive impact of science and technology upon individuals, societies and the environment. We understand the social responsibility of scientists and engineers as requiring from them a meaningful contribution to the safeguarding or promoting of a peaceful, just and sustainable world society. We believe that this responsibility follows from widely shared ethical norms, to be discussed later, such as the duty to do good, or at least not to do harm. Science and engineering education should empower its students for this. ${ }^{1}$

Many of the problems confronting Western and global society are closely related to science and technology. These problems include:

\footnotetext{
${ }^{1}$ Here "science and technology" includes engineering, and "scientists and engineers" is meant to include technologists. Science is the activity of systematically producing new knowledge based on observation or experimentation, and/or the knowledge resulting from this activity. Technology and engineering consist of inventing, developing and producing practical things, processes or methods (often but not necessarily based on science), and/or the products of these activities.
} 
1. The large scale pattern of unsustainable development, depletion of natural resources, environmental pollution, and irreversible ecological harm;

2. Many human activities impose ever-increasing harms and risks upon others. Often those who experience these risks and harms have not consented to the activities. Further, they themselves may also be engaged in similar or other risk- and harm-generating activities;

3. The lack of effective control of the risks and negative effects of science and technology with regard to both the malevolent use of science and technology, and the unintended side effects of "benevolent" uses. Examples are climate change caused by the exploitation of fossil fuels; privacy and control issues attached to information and communication technology; and safety and security issues associated with specific fields such as bioscience and technology, nuclear technology and information technology;

4. The unequal distribution of wealth and natural resources, both within nations and globally. Not merely are the less well-off deprived of many natural and technological resources. Also, through exploitation of their own wealth, the wealthy may actively harm the less privileged, e.g. through pollution and overconsumption of resources;

5. Science and technology have a profound influence on human biology, relations, and civilization that can be assessed differently (positively or negatively) according to one's ethical values/orientation;

6. Substantial portions of contemporary research and development take place in secrecy and (hence) lack transparency. This is problematic since, among other things, there may be risks associated with the research; ${ }^{2}$

7. The large-scale military use of science and technology is an important and often decisive factor in the use of power and violence by nations and other actors;

8. Increasingly, scientists and engineers fulfil non-neutral, "pseudo-political" or "interested" roles in contemporary "post-normal"3 science and technology. These new roles for scientists and engineers raise questions as to whether and how such roles are consistent with traditional norms for science such as disinterestedness and organised scepticism, ${ }^{4}$ and whether scientists and engineers are properly educated for their changed role.

Scientists and engineers face these and other issues both in their professional work and as citizens. Given the severity of these current and future concerns, the question arises as to whether the actual practices and contents of science and engineering education are adequate and sufficient. This leads to additional questions: What are the driving forces behind education for social responsibility

\footnotetext{
${ }^{2}$ Tom Børsen (2013) reports on a relevant discussion among scientists on this issue.

3 Post-normal science refers to scientific inquiry in situations where "facts are uncertain, values in dispute, stakes high and decisions urgent" (Funtowicz and Ravetz 1993).

4 These norms, together with the norms of universalism and communism (later renamed communalism), were first described in 1943 by the sociologist of science Robert Merton (Merton 1973). Disinterestedness requires personal and group interests to be subordinated to the interests of research. Organised scepticism implies "the temporary suspension of judgment and the detached scrutiny of beliefs in terms of empirical and logical criteria” (Merton 1973, p. 277).
} 
and how effective are they? What obstacles are encountered in teaching social responsibility? What can be learned from examples and how can new initiatives be stimulated?

The contributions to this special issue originate from an international workshop devoted to these questions, entitled "Preparing for social responsibility: Teaching ethics, peace and sustainability to students in science and engineering", held in Delft in October 2010. ${ }^{5}$ It was the third conference, after similar events in Copenhagen $(2005)^{6}$ and Hamburg (2008), ${ }^{7}$ organised by an informal European network of individuals who at their respective universities are involved in teaching peace, ethics and sustainability for students in science and engineering. At the time of publication, a fourth conference has taken place in Bradford in July 2012. ${ }^{8}$ Other conferences may follow as the network expands to foster teaching for social responsibility through international cooperation.

Within the network, a shared vision has developed with regard to the characteristics that are needed in teaching to prepare students for dealing in a socially responsible way with issues/concerns like those identified above. This shared vision evolved during the previous workshops in Copenhagen and Hamburg (Rathje et al. 2008) and was reaffirmed during the Delft 2010 workshop. There is consensus within the network that particular goals and features should be incorporated into science and engineering curricula in order to adequately prepare students for social responsibility:

- A broad knowledge base not restricted to science and technology but reaching out to pertinent elements of the humanities such as philosophy, sociology, political sciences, psychology, history, law and other areas, insofar as relevance is identified;

- Teaching approaches that are also multi-, inter- and/or transdisciplinary; Such approaches are necessary to understanding the historical development of science and technology within society, the problems and risks that have resulted, and the possibilities for dealing with these problems and risks now and in the future.

- Reasoning and communication skills, including the capacity to apply critical faculties not merely to technical and scientific issues, but to ethical, social and political issues as well;

- Awareness of both distinctive and shared values in society, and cultural differences, as well as awareness of possible approaches to address value-based issues;

- Awareness of the influence of social institutions such as hierarchical organisations, the law, and political institutions on the (positive or negative) impact of science and technology in society, and knowledge about available options for positive change;

- Activities and knowledge that enhance a student's attitude, involvement, commitment, and willingness to act in a socially responsible manner;

\footnotetext{
5 See http://ethicsandtechnology.eu/socialresponsibility/ (Accessed October 31 2013).

${ }^{6}$ Report available at http://portal.unesco.org/shs/en/files/8735/11289332261TeachingEthics_Copenhagen Report.pdf/TeachingEthics_CopenhagenReport.pdf (Accessed November 5 2013).

${ }^{7}$ See http://www.znf.uni-hamburg.de/ethics-and-peace.html (Accessed November 5 2013).

${ }^{8}$ See http://www.brad.ac.uk/bioethics/Activities/2012Conference/ (Accessed November 5 2013) and Yearbook of Biosecurity Education 2012 edited by Judy Sture (in press).
} 
- Active learning practices, such as role playing, the use of case studies, and relevant project and community work.

Of course these characteristics do not fully determine the courses, teaching content and methods, nor the amount of curriculum time that is necessary or desirable. Given the considerable challenges posed by the ethical and social problems that contemporary science and technology are facing, it is at least plausible that appropriate teaching for social responsibility would require considerable curriculum time, staff, and (hence) money. A prevailing theme in the preceding workshops had been that proponents of this teaching frequently experience difficulties in the competition with other claimants of academic curriculum time and resources. Indeed there are clear signs that education for social responsibility is not implemented, and does not receive the commitment and support, to the extent that it should. On the basis of available information, both from the literature and the experience of members of our network, we conclude that in general this teaching plays a marginal role in the science and engineering curriculum, when measured in curriculum time, number of credit points involved, whether courses are required or elective, and the institutional support provided by the university. In light of the array of social and ethical concerns associated with science and technology, the limited presence of teaching for social responsibility in the science and engineering curricula appears surprising. As will become clear below when we discuss the barriers to teaching for social responsibility, there is no positive sign let alone evidence for an assumption that the way in which universities currently prepare students in science and engineering for social responsibility is adequate or sufficient.

Against the above background, three themes were singled out for the Delft workshop, and speakers were invited who could contribute to these themes:

1. Why and what?-Why is it necessary that science and engineering programmes should prepare students for social responsibility? What is needed? Which competencies, skills, and knowledge should students acquire? What are appropriate teaching methods and contents? Many contributions to this issue deal with one or more of these themes, including those by Esat Alpay (2011), Tom Børsen and colleagues (2013), Christelle Didier and Antoine Derouet (2011), Neelke Doorn and Otto Kroesen (2011), Robert Geerts (2013), Iris Hunger (2013), Wolfgang Liebert (2013), Masamichi Minehata and colleagues (2011), Kathryn Nixdorff (2013), and Haldun Ozaktas (2011).

The question of who should teach was not an explicit theme, but several contributions report on valuable experiences regarding this important issue.

2. How to work around obstacles within the university and achieve results?-The articles by Børsen and co-workers (2013), Liebert (2013), and Ozaktas (2011) as well as the commentaries by André Baier (2013), Gerd Michelsen (2013) and Hartwig Spitzer (2013) provide instructive experiences regarding these themes.

3. How to connect with external partners?-Possible partners are accreditation bodies, professional organisations of engineers and scientists, student organisations, (inter)national bodies such as UNESCO (United Nations Educational, Scientific and Cultural Organization) and the conventions against nuclear, 
chemical and biological weapons, and politicians. Annina Takala and Kati Korhonen-Yrjänheikki (2011) provide an example from Finland involving an organisation of engineers.

In total, eight presentations have evolved into the articles in this special issue, coming from Denmark, Finland, France, Germany, The Netherlands, Norway, Turkey, the United Kingdom and Japan. For each of these contributions a commentator was invited to provide comments and to add their own experience. The commentators originate from Germany, Ireland, the Netherlands, and Spain. The resulting collection of eight articles and eight commentaries covers many aspects of the three themes, but connecting with external partners has received less attention than the first two. This reflects the state of affairs in the conference in 2010.

\section{Overview}

There are a number of important issues that are relevant for all contributions, and recurring themes and issues are apparent in the experiences and reflections presented in the separate contributions. The section "Opportunities Created by External Demands for Teaching Social Responsibility" deals with calls for teaching activities aimed at preparing scientists and engineers for social responsibility that have been expressed by external social, political and professional organisations. Such requests can legitimise those who want to promote or implement social responsibility teaching within their universities. We next discuss the actual extent of ethics courses for students in science and technology at American and European universities, and we discuss certain limitations of that teaching from the point of view of preparing students for social responsibility. Next we summarise the perspectives that the authors of this special issue bring to the question "Who should teach?" The following section explores the barriers, challenges and obstacles for successful introduction of teaching for social responsibility, drawing on the contributions for examples. Then the terms "social responsibility" and related expressions are explored with the expectation that this will help to identify and clarify appropriate subject matter for courses aimed at teaching social responsibility. Next we discuss what we call the top-down/bottom-up distinction. Initiatives from teachers, individually or as groups, represent the "bottom-up" aspect, but for (lasting) success they depend upon adequate "top-down" support from the university administration. The last section is devoted to what we see as priorities for future activities of the network from which the topic of this Special Issue originates. These priorities are the identification of teaching contents, and the formation of alliances with external partners.

\section{Opportunities Created by External Demands for Teaching Social Responsibility}

Many political, social and professional organisations have expressed the need for teaching activities aimed at preparing scientists and engineers for social responsibility. Such demands may create opportunities for proponents of this teaching within universities to realise their goal. 
A development that is particularly relevant for the European area is the Bologna process. Its purpose is the creation of a European Higher Education Area (EHEA), by making academic degree standards and quality assurance standards more comparable and more compatible throughout the European Union. ${ }^{9}$ In this context European Ministers responsible for Higher Education have adopted an overarching framework for qualifications in the European Higher Education Area. The following learning outcomes laid down in these so-called "Dublin Descriptors" are relevant for education for social responsibility. At graduation

- Bachelor's students "have the ability to gather and interpret relevant data (usually within their field of study) to inform judgements that include reflection on relevant social, scientific and ethical issues."

- Master's students "have the ability to integrate knowledge and handle complexity, and formulate judgements with incomplete or limited information, but that include reflecting on social and ethical responsibilities linked to the application of their knowledge and judgements."

- Doctoral students have the ability to "communicate with their peers, the larger scholarly community and with society in general about their areas of expertise" and to "promote, within academic and professional contexts, technological, social or cultural advancements in a knowledge-based society." 10

The education that is required to realise these learning outcomes can be seen as necessary for an adequate preparation for social responsibility, irrespective of which precise definition of social responsibility one adopts. Therefore the Bologna process seems to open possibilities for implementing elements of teaching for social responsibility within science and engineering programmes. Michelsen (2013) provides an example in this issue. However, the actual influence of "Bologna" and the Dublin descriptors should not be overestimated. For example, Fabregat (2013) states that the Dublin descriptors or similar criteria have no relevant effect on the assessment of teaching and research performance at Spanish universities. Indeed, it is possible that "Bologna" may even have outright negative effects (see below).

In addition, the criteria formulated for the accreditation of teaching programmes, such as the ABET 2000 criteria in the USA, may also open possibilities for promoters of teaching for social responsibility. ${ }^{11}$ The influence of the ABET accreditation criteria extends also to Europe, as is exemplified in Ozaktas'

\footnotetext{
9 The website http://ec.europa.eu/education/policies/educ/bologna/bologna.pdf (Accessed 28 October 2013) provides the text of the Bologna declaration adopted in 1999 by the European Ministers of Education, and a commentary by the Confederation of EU [European Union] Rectors' Conferences and the Association of European Universities (CRE).

10 http://www.bologna-bergen2005.no/EN/BASIC/050520_Framework_qualifications.pdf (Accessed 28 October 2013).

11 The most relevant criteria of ABET (formerly known as the Accreditation Board for Engineering and Technology) are: "The program must have documented student outcomes that prepare graduates to attain the program educational objectives: [...] (f) an understanding of professional and ethical responsibility; ... (h) the broad education necessary to understand the impact of engineering solutions in a global, economic, environmental, and societal context; ... (j) a knowledge of contemporary issues [...]"

Source: http://www.abet.org/uploadedFiles/Accreditation/Accreditation_Step_by_Step/Accreditation_ Documents/Current/2013_-_2014/eac-criteria-2013-2014.pdf (Accessed 28 October 2013).
} 
contribution (see also Spitzer 2013). Ozaktas (2011) reports that there is a tendency in Turkey to fulfil the ABET requirements, but with minimal cost resulting, for example, in very big classes. Conlon (2013) discusses in a more general way the influence in Ireland of these accreditation criteria. He concludes that they "can help in legitimising the broadening of engineering education even though their mere existence does not necessarily lead to a curriculum which adequately addresses the social and political issues involved with engineering." Didier and Derouet report that several French institutions have issued recommendations concerning the preparation of students for social responsibility. However, up till now, "Most engineering schools seem to ignore these recommendations because they assume the courses that are intended to broaden the student's mind already exist in the curriculum" (Didier and Derouet 2011).

The view that the ethical, social and ecological challenges of scientific and technological development require appropriate education in social responsibility for science and engineering students at the university level is actively supported by professional organisations in some European countries. Focussing on education for sustainable development, Takala and Korhonen-Yrjänheikki (2011) provide an example involving the Finnish Association of Graduate Engineers TEK.

Minehata and co-workers (2011) illustrate, in the case of biosecurity education, that global institutions such as the InterAcademy Panel: The Global Network of Science Academies (IAP), the World Health Organisation (WHO), the Biological Toxins and Weapons Convention (BTWC), and the Organisation for Economic Cooperation and Development (OECD) all are concerned with the appropriate education of young scientists. But Minehata and colleagues (2011) also report that in spite of this, and in spite of the fact that life scientists across the globe show a lack of awareness of dual-use issues in the life sciences and technology, and that there is only limited availability of biosecurity tutoring at the university level across the globe, university lecturers face a range of difficulties in introducing teaching aimed at awareness raising.

In the field of education for sustainable development, the United Nations (UN) and UNESCO (United Nations Educational, Scientific and Cultural Organization) play an active role. ${ }^{12}$ The UN declared the years from 2005 to 2014 as the "World Decade of Education for Sustainable Development". The national activities are organised by the various national UNESCO Commissions. In six European countries UNESCO sponsored university chairs for "Higher Education for Sustainable Development". Together with the German rectors Conference of universities, the German UNESCO Commission adopted the resolution "Universities for Sustainable Development" in 2010. ${ }^{13}$ The UN and UNESCO plan to have a "Global Action Programme on Education for Sustainable Development" in the

\footnotetext{
12 UNESCO is also active in ethics, more specifically bioethics. (See Ten Have 2010).

13 (http://www.bne-portal.de/fileadmin/unesco/de/Downloads/Dekade_Publikationen_national/Declaration_ 2520_2522Universities_2520for_2520Sustainable_2520Development_2522.File.pdf.) (Accessed 5 November 2013).
} 
years after 2014. ${ }^{14}$ UNESCO has also published a list of generic sustainability competencies that are at least in part relevant to the topic. ${ }^{15}$

One can conclude that the effects of externally formulated demands for education for social responsibility are mixed. They may create opportunities to promote this education within the universities, and this Special Issue provides examples of that, but there are also indications that, up till now, their overall impact has been limited at best.

\section{Teaching for Social Responsibility: The Actual Teaching Effort at American and European Universities}

The focus of this section is on ethics courses for students in science and engineering. These courses may be the most obvious candidates of courses that provide education for social responsibility.

Using results of a survey of undergraduate catalogues of ABET-accredited institutions published by K.D. Stephan (1999), Joe Herkert (2000) estimated that nearly $80 \%$ of engineering graduates in the USA attended schools that did not have an ethics-related course requirement for all students. While $17 \%$ of institutions and $8 \%$ of graduates did have one or more required courses with ethics-related content, these courses were usually not courses in engineering ethics per se, but rather courses in such areas as philosophy or religion (Herkert 2000). ${ }^{16}$ The proportion of science and engineering graduates that take ethics courses may have grown in the last decade, as a consequence of the inclusion of ethics related learning outcomes in accreditation criteria such as the ABET 2000 criteria, and the increased emphasis on responsible conduct of research (RCR) in the science curricula. These developments, while originating from North America, have also extended to at least some universities in Europe. In spite of this, Raffaella Ocone, writing about the challenges of accrediting

\footnotetext{
${ }^{14}$ http://unesdoc.unesco.org/images/0022/002223/222324e.pdf (Accessed 5 November 2013).

152012 Report on the UN Decade of Education for Sustainable Development, Shaping the Education of Tomorrow, Edited by UNESCO 2012 http://unesdoc.unesco.org/images/0019/001914/191442e.pdf On p. 44 the following generic competencies are mentioned: Competence to think in a forward-looking manner, to deal with uncertainty, and with predictions, expectations and plans for the future; Competence to work in an interdisciplinary manner; Competence to see interconnections, interdependencies and relationships; Competence to achieve open-minded perception, trans-cultural understanding and cooperation; Participatory competence; Planning and implementation competence; Ability to feel empathy, sympathy and solidarity; Competence to motivate oneself and others; Competence to reflect in a distanced manner on individual and cultural concepts.

These Generic Sustainability Competencies are based on the ideas of "Gestaltungskompetenz" developed in Germany (de Haan 2010; Michelsen and Adomssent 2007). Maik Adomssent and Thomas Hoffmann (2013) explain the concept of "Gestaltungskompetenz" (shaping competence) and contrast it with other concepts (e.g., Learning for Change-Global Learning Approach). Arnim Wiek and colleagues (2011) are another important resource for the discussion of competencies.

16 More information about teaching of ethics for engineers in Europe and in Australia can be found in Zandvoort et al. (2000b) of which "Engineering ethics education in the USA: Content, pedagogy and curriculum" (Herkert 2000) was a contribution, and in Zandvoort (2008b). For useful information about the teaching of ethical and professional issues within engineering programmes in the USA see also the work of Anne Colby and William Sullivan (2008) and Larry Shuman and colleagues (2005).
} 
engineering ethics, concludes from a survey carried out in 2004 by the Royal Academy of Engineers that among UK engineering departments, "ethics teaching has taken hold in only a small proportion of Departments" (Ocone 2013: p. xxx.e3).

There exists little detailed information about the numbers of students in science and engineering taking a course on ethics or related to social responsibility, or on the amount of curriculum time devoted to those courses. Anecdotal evidence suggests that curriculum time is often quite limited. As an example, Douglas May and Matthew Luth, reporting on the relative effectiveness of ethics education courses for students in engineering and science created through a multi-institutional faculty development program in the USA, note in passing that "departments were reluctant to allocate more than 1-2 credit hours ${ }^{17}$ for students taking a [stand alone] research ethics course" (May and Luth 2013). There is no reason to assume that what May and Luth observed is an exception. At the same time, programmes in the responsible conduct of research are becoming increasingly widespread in the U.S. given that both of the major federal funders of research in the U.S. (the National Institutes of Health $[\mathrm{NIH}]$ and the National Science Foundation [NSF]) require trainees to receive education in the responsible conduct and reporting of research.

Moreover, the NIH has identified broader concerns such as "the scientist as a responsible member of society, contemporary ethical issues in biomedical research, and the environmental and societal impacts of scientific research" as well as topics in research practice, as appropriate elements of RCR education.

Based on the joint wisdom of the organisers and participants of the Delft workshop, the situation in Europe is similar. Certainly not all students in science and engineering are exposed to significant ethics or social responsibility related curriculum content. Where such teaching does exist, it either takes the form of a stand alone course, or is integrated in a larger curriculum element such as a design course in engineering. In rare cases, the number of ECTS credits ${ }^{18}$ is as large as 6 , but courses or course elements of $1,1 \frac{1}{2}, 2$ or 3 ECTS credits are much more common.

One can tentatively conclude that, on the whole, the amount of curriculum time devoted to ethics-related topics is quite minimal relative to the ethical and social problems attached to science and engineering. The relative absence of teaching aimed at preparing students for social responsibility could perhaps be justified if other social institutions and actors besides science/technology and scientists/ engineers, such as the political and legal systems, or even 'the market', could be relied upon to assure that the results of science and technology are used to positive effect in society. In that case, scientists and engineers would not need to be actively engaged in addressing the proper functioning of these social institutions. However, none of the ethical and social problems mentioned in the beginning is under the effective control of any of these social institutions. Therefore, scientists and engineers, being citizens and having moreover a significant role in producing new knowledge and developing new technological applications, need to ascertain that

\footnotetext{
17 One credit hour is equivalent to one hour of class time per week for one semester, with the expectation of two additional hours of study outside of class. For one semester 15 semester credit hours is the normal full load. That means that 1 American credit hour is approximately equal to 2 European ECTS.

18 One academic year corresponds to 60 ECTS-credits that are equivalent to $1500-1800 \mathrm{~h}$ of study.
} 
these social institutions are up to the task of governing the beneficial application of science and technology in the world, and, when necessary, to help in improving these institutions.

\section{The Limitations of Current Ethics Courses in Preparing Students for Social Responsibility}

An additional concern arises when the contents of existing ethics courses is taken into consideration. There exists a widespread approach to the teaching of ethics to engineering students in which the exclusive focus is on the decisions and actions of engineers as individuals in their workplace ("microethical issues") rather than an evaluation of the broader ethical, legal and social impacts of engineering projects as a whole ("macroethical issues"). ${ }^{19}$ Although this narrow approach to education in engineering has frequently been criticised in the literature as being incomplete and/ or misleading ethics, it persists on a large scale, as can be inferred from accounts in the educational literature and from the contents of widely used textbooks in engineering ethics (For further discussion and for references to the literature see Conlon and Zandvoort 2011).

The situation in science education is similar in that the focus is on individual ethical issues and behaviour rather than "macroethical" or policy issues. This at least can be concluded from a series of articles and commentaries on the teaching of research ethics that was published in 2002 in Science and Engineering Ethics. A main point that was stated, discussed and regretted by several of the contributors was that the teaching of ethics to researchers tends to focus on the behaviour of individual scientists, and on ethical norms that are considered internal to the practice of science, such as that researchers should not fabricate data or commit plagiarism. Instructional areas that focus on the social responsibility of scientists, that is, on their responsibility to the larger society, receive much less attention or are completely ignored (Zandvoort 2008a). (Pimple (2002) observes that none of the Core Instructional Areas issued by the United States Public Health Service (PHS) clearly correspond to any of the items in his Domain 6 of research ethics (Social Responsibility). He calls this a disturbing gap. Hackett (2002) confirms the gap and calls it regrettable. Slaughter (2002) confirms that aspects of the domains, as specified by Pimple, capture important areas of ethics not usually included in governmental and science association treatments [of requirements for the education of researchers]. Weil (2002) agrees that scientists' responsibilities to the larger society have received less attention than ethical issues internal to the practice of science. $^{20}$ Kline (2013) makes it clear that this emphasis on individual ethical

\footnotetext{
${ }^{19}$ For further discussion of the concepts of microethics and macroethics see "Ways of thinking about and teaching ethical problem solving: Microethics and macroethics in engineering" by Joseph Herkert (2005).

20 There is a recent increase in interest in "macroethical" issues including policy issues in educationrelated discussions in the USA. Examples are Byron Newberry (2010) and other contributions to the 16(3) issue of Science and Engineering Ethics which was devoted to the theme of risk and responsibility. However whether this attention to "macroethical" and policy issues has been translated into teaching remains an open question.
} 
behaviour at the neglect of a consideration of the social implications of science is still the default situation in ethics courses for scientists.

Emphasis in science and engineering education on "microethics" (that is, the ethical issues in engineering and research practice), does not provide students with adequate preparation for dealing with the current and future challenges of a technological world in a responsible way, either as professionals or as citizens. Insufficient attention (or sometimes no attention at all) is given to the critical study of the organisational, social, legal and political context in which scientists and engineers work, to reveal the larger, collective "macroethical" aspects of their work, and to enable them to develop and evaluate possible solutions to manifest problems and to help implement such solutions. Several of the authors of this present special issue express this conclusion, each in their own way referring to their own context.

\section{Who Should Teach?}

Who should teach courses on social and ethical issues for students in science or engineering? Should the teachers be recruited from the science and engineering staff? Should they have a background in the humanities or social sciences and should they (therefore) be based in the humanities and social science faculties? Or should the teaching be done by teams consisting of teachers with different (inter)disciplinary backgrounds and based in different faculties of the university?

Students in science and engineering generally have as their role models the scientists and engineers. The involvement of members of the science and engineering faculty forcefully demonstrates to their students that the broader, ethical legal and societal implications of science and engineering are of concern to the science and engineering communities. That they are willing to contribute their most limited (and in some sense most valuable) resource, their time, speaks volumes to students. Furthermore, scientists and engineers often bring a wealth of real world experience regarding the unexpected though predictable consequences of scientific and technological applications. Their firsthand accounts can meaningfully inform students' misapprehensions regarding the universally beneficial nature of science and technology. Thus, who teaches is important, in part because of what the answer says about the significance of social responsibility for the science and engineering communities (Baum 1980; Bird 1993, 1994, 1999; Colby and Sullivan 2008; Harris et al. 1996; Zandvoort et al. 2008). However, team teaching that also involves faculty from the social sciences and the humanities reinforces the importance of the perspective of other stakeholders outside the science and engineering communities, and highlights the valuable knowledge and insights of those disciplines in recognising and addressing the ethical, legal, and social implications of science and technology.

The contributions to this special issue illustrate a number of different constellations of instruction for teaching social responsibility. In some instances teaching activities are primarily delivered by engineers or natural scientists (Alpay 2011; Hunger 2013; Minehata et al. 2011; Nixdorff 2013). Ozaktas (2011) provides an example of a dedicated engineering teacher working in isolation within his 
university. At the same time, there are also courses that are primarily delivered by social science experts: Courses described by Doorn and Kroesen (2011) are primarily given by ethics experts from the faculty of Technology, Policy and Management of TU Delft. Yet, in at least some cases, interested staff members from the engineering departments are involved to tutor groups or to give single lectures. At TU Delft many consider this the ideal situation. Henk Zandvoort and colleagues (2008) report on experiences with this kind of teaching in Delft.

Examples of interdisciplinary team-teaching of various kinds are described by Liebert (2013), Børsen and colleagues (2013), Geerts (2013), Michelsen (2013) and Spitzer (2013). The teachers of the interdisciplinary study concentrations at TU Darmstadt come from engineering disciplines, the natural sciences, social sciences and the humanities. They deliver, for example, plenary lectures that deal with the big challenges that global society is facing, such as climate change and hazardous waste disposal. This type of collective, but still additive interdisciplinary lecturing originated and has flourished at TU Darmstadt since the 1980s. In addition, there are seminars alone, or in combination with group/individual projects or role playing, which are organised jointly by professors from both the engineering and natural sciences, and the social sciences and humanities. This is true interdisciplinary team teaching.

Thus, the contributions to this issue describe a number of different teacher constellations. We noted in our network that apparently in those cases where interdisciplinary team teaching is practiced, the participants are generally positive about it. However, perhaps it is not a question of disciplinarity or interdisciplinarity of the different instructors, but a question of narrow or broad competencies. As Liebert (2013) states: "Team-teaching involving instructors from at least two disciplines might be helpful [...], but that is not a requirement. Crucial is the involvement of interdisciplinarily educated or experienced teachers having a broader scientific background as well as a dedicated problem-oriented interest".

\section{Barriers to Teaching for Social Responsibility}

There is an apparent consensus throughout society regarding the importance of broadening the perspectives of science and engineering students in order to enhance their social responsibility competencies (e.g., knowledge, analytical capabilities, and ethical sensitivity). This societal concern and interest has inspired some valuable teaching activities at some universities. In spite of this, most universities and most natural science and engineering departments in Europe and in the US have not embraced this aspect of science and engineering education. This was one of the conclusions of the 2008 Hamburg workshop (Rathje et al. 2008) and that conclusion is further supported here. There obviously exist important obstacles that must be surmounted for the successful introduction of teaching for social responsibility.

One barrier is the degree to which the academic community, and the science and engineering communities in particular, have come to see themselves as independent from society rather than as a part of it. The current situation is understandable as the result of a long historical development in which universities were successfully established as a social subsystem, to a great extent independent from other 
subsystems of society. The academic disciplines within universities, which determine the contents of the educational curricula, are the result of an on-going process of academic specialisation and differentiation. ${ }^{21}$ Liebert (2013) describes the challenges that interdisciplinary (or transdisciplinary) teaching activities are facing at TU Darmstadt, a discipline-based university. While referencing the Spanish experience, Fabregat's (2013) important observations apply more generally.

Another barrier is the idea that the ambiguity of a topic justifies its exclusion from science and engineering education. Ozaktas observes that "most engineering courses are traditionally taught in a fashion which is highly divorced from real engineering practice", and that "the rigor of engineering education leaves little room for reflecting on the nature of technology and science and their interactions with society". Further Takala and Korhonen-Yrjänheikki (2011) state that "Because (sustainable development) is an ambiguous concept, it is a challenge especially to engineers and engineering education, as they have traditionally focused on teaching 'absolute facts'”. In addition, Børsen and colleagues (2013) “... [explain] the lack of ethical elements in university science education by identifying the logic underlying science curricula: they are about learning to solve scientific puzzles that have exactly one answer. Ethical problems, however, are contextual and complex and seldom have only one solution. This explains why ethical elements are excluded from mainstream university science programs: they do not fit in." Although engineering problems usually do not have only one answer, there is general resistance to incorporating ethical and social problems, not merely in science education, but also in engineering education (Ozaktas 2011; Takala and KorhonenYrjänheikki 2011; Børsen et al. 2013). Fabregat (2013) points to another possible explanation: assessment of non-technical subjects is more difficult. Whatever the reason, the mere fact that a topic has ambiguous aspects is not a valid reason to exclude it from the educational programme, as Geerts (2013) points out.

The contributions in this issue thus identify and examine some of the barriers between society in general and science and engineering disciplines that lead to a selective perception of socio-technical problems by scientists and engineers. Their perception is selective in that issues that are considered "ambiguous" or not amenable to disciplinary analysis or problem solving tend to be discarded. As the curriculum is predominantly determined by these discipline-oriented scientists and engineers, socially desirable learning goals aimed at social responsibility skills and competencies may not be sufficiently reflected in the curriculum.

In addition, obstacles within a university between natural science and engineering departments on the one hand, and social science and humanities departments on the other, can make it difficult for teaching staff to work together on interdisciplinary courses. This problem is related to the fact that universities are (usually) organised along the lines of traditional disciplines, as is illustrated in Liebert (2013). That these challenges are not insurmountable is demonstrated by Leuphana University Lüneburg (Germany) which has successfully implemented a universitywide teaching programme with strong interdisciplinary elements (Michelsen 2013).

\footnotetext{
${ }^{21}$ The works of Douglas Sloan (1978), Stichweh (1984), Luhmann (1990), and Weingart (2010) all speak to this issue.
} 
At the same time, Leuphana University's success may reflect the fact that it is a relatively young university. A similar effect can be observed in the early years of the universities of Bremen (Germany) founded in 1971 (Meier-Hüsing 2011) and Twente (Netherlands) opened in 1964 (Geerts 2013).

Even from the perspective of students, similar barriers become evident: "Ethics teaching in engineering can be problematic because of student perceptions of its subjective, ambiguous and philosophical content." (Alpay 2011). For that reason "[t]he use of discipline-specific case studies has helped to address such perceptions, as has practical decision making and problem solving approaches based on some ethical frameworks. However, a need exists for a wider range of creative methods in ethics education to help complement the variety of activities and learning experiences within the engineering curriculum" (Alpay 2011).

Moreover, the adequacy of current accreditation processes to guarantee sufficient attention to socially desirable teaching goals is questionable. Conlon (2013), writing on the Irish situation, states that “... accreditation processes do not adequately interrogate the extent to which programmes address the specified learning outcomes. Accreditation panels,... are composed of industry representatives and engineering academics who seem to lack the expertise to adjudicate the provision of content relating to social responsibility within engineering programmes." To better address the barriers between society as a whole, and science and engineering disciplines, he considers it necessary for the interests of society to be represented on accreditation panels by perspectives beyond those of industry alone. Fabregat (2013), writing about Spanish university education, makes an important observation that is similarly relevant: "Inside the university, the experts who assess the work of a scientist (in the natural sciences) or engineer are scientists and engineers themselves. They are neither experts in the social sciences or humanities, nor individuals who represent the general interest of the society regarding the education of engineers. In other words, and this is also noted by Liebert in his contribution (Liebert 2013), it is easier and more common to evaluate performance within specific technological fields than performance in the ethical and social aspects of engineering" (Fabregat 2013).

While the Bologna process can be an opportunity for developing educational programmes in social responsibility, it can also have unintended negative effects. "Bologna" has in some cases led to the inclusion of a "homogenisation" stage in the Master's of Science (MSc) programmes, which now accept students from a much broader range of Bachelor's of Science (BSc) programmes than what was the situation before. There may also be a tendency toward increased specialisation in the new MSc programmes. Both trends may put pressure on the space in the curriculum that is available for teaching about social responsibility (Fabregat 2013). In this context, it should be noted that the Bologna Declaration and the subsequent Bologna process have not provided for monitoring and evaluating whether and how the Dublin Descriptors are implemented in actual educational programmes. Significant evaluation of the implementation of the Bologna process has actually taken place in at least some European countries (e.g., Finland). But while the Finnish evaluation report (Finnish Higher Education Evaluation Council 2012) mentions mobility and competencies for the labour market as important objectives 
of the Bologna process in Finland, no reference is made to the Dublin Descriptors or to social responsibility.

\section{Defining Social Responsibility: Implications for the Contents of Education for Social Responsibility}

An explicit definition of "social responsibility" can help to enhance understanding of what is needed for teaching for social responsibility. We propose the following definition: an activity or action within science and technology is socially responsible if it satisfies certain ethical principles, and socially irresponsible if it does not satisfy those principles. ${ }^{22}$ Similarly, the wider use of scientific and technological products in society could be labelled socially responsible if it does not violate such principles. A decision can be called socially responsible or not, depending on whether it leads to a socially responsible activity.

In order to impart specific content to these formal definitions, the ethical principles that must be satisfied should be specified. Which principles are needed to guarantee or at least promote a peaceful, just, and sustainable world? Which principles should govern the work of scientists and engineers in the value-laden contexts of "post-normal" science and development?

Related questions arise: How can individuals act in a socially responsible way within groups, organisations, and institutions? How should one understand the social responsibility of private and public organisations, groups, and institutions (e.g., corporate social responsibility and scientific social responsibility), and what does it imply for the members of those entities? Is it possible to separate individual responsibility from the wider social, cultural, organizational and economic context? And is there an obligation to take action when one encounters social irresponsibility?

None of these questions has received satisfactory and sufficient answers. In reality, disagreement on these questions abounds in society as well as within science, engineering and technology. Even when there is agreement about certain basic ethical principles, disagreement is apt to arise when the general principles are applied to specific cases. Important basic ethical principles that are directly relevant for scientists and engineers include:

- The do no harm principle: People are free to act as they please, as long as they do not harm others.

- The precautionary principle which reads in one of its formulations: A "proponent of an activity posing uncertain risk bears the burden of proving that the activity poses 'no' or an 'acceptable' risk before the activity can go forward". (Rogers 2003, p. 386)

\footnotetext{
22 Billy V. Koen has similarly defined ethical decision making and acting of engineers as that decision making and acting that is in agreement with the ethical norms for engineers. An important difference between Koen and the present authors is that Koen writes on the assumption that there exists, or can be found, a practical consensus within the profession and in the broader society about what these norms are, and that they could be used to decide whether a particular practice of engineers is, or is not, ethical (Koen 2003). However such a consensus does not exist and this has implications for the teaching of ethical and social responsibility.
} 
- The principle of (free, voluntary) informed consent: Activities that (may) have harmful effects for others require the informed consent of those others in order to go forward.

- The principle that actors can be required to repair or compensate harm ensuing from activities for which the actors had not obtained the informed consent of those subjected to the (potential) harm.

- The principle of freedom of speech.

The do no harm principle has sometimes been characterised as a "negative freedom", as distinguished from "positive freedom". Where the do no-harm principle translates "merely" into the obligation not to harm others, positive freedom may lead to the obligation to actively help others. ${ }^{23}$

Ethics as an area of scientific study could be defined as the study of different possible ethical principles and their implications. This can be extended to the comparison of the ethical principles, and their implications, with actual practice, in order to establish how that practice could be improved. Are accepted or desired ethical principles consistent with, or supported by, the existing procedures for decision making, the legal systems, the rules and cultures of organisations, the laws and rules that govern economic activities? And if there are discrepancies, how could the legal system, organisational and economic practices, and the procedures for collective choice be altered so as to bring them in better agreement with ethical principles? ${ }^{24}$ The abilities to research and analyse, reflect upon, discuss, and evaluate such issues constitute important competencies for scientists and engineers for deciding and acting in a socially responsible way. While this may go beyond the realm of science and engineering per se, it is within the domain of all members of society, and hence should have implications for all higher education. However, as producers of science and technology, scientists and engineers are especially involved. It is a consequence of the fact that science and technology are not value neutral activities. It is the task of education to empower students with these competencies.

It appears that, in principle, there is considerable agreement within society on the correctness or desirability of certain basic ethical principles such as those mentioned above. But at the same time there exist important discrepancies between such ethical principles and actual practice, as the following two examples illustrate.

1. The principle of informed consent is generally considered a sound and obvious ethical principle. For instance, it is considered as almost inviolable in medical ethics. Consistent with this, authors in the field of engineering ethics have assumed or suggested that the principle of informed consent should equally hold for engineering projects (Baum 1980; Harris 1998; Martin and Schinzinger 1996; Schlossberger 1997). Their reasoning is that all engineering projects are actually social experiments with uncertain outcomes. This, so they argue, places

\footnotetext{
${ }^{23}$ In this vein, and referring to philosopher G.W.F. Hegel's Rechtsphilosophie, the philosopher Axel Honneth has written about the concept of social freedom, from which could follow an obligation to discuss the question of what kind of socio-techno-world to create. This might translate into an obligation of engineers and scientists to help to realise a just, peaceful, sustainable world. (Honneth 2013).

24 See on this for example, "Good engineers need good laws" (Zandvoort 2005).
} 
obligations and responsibilities upon engineers, who should see to it that those who are subjected to the consequences of these social experiments are properly involved in the decision making regarding those experiments. ${ }^{25}$ Yet many decisions regarding technological projects and activities are actually governed by (national) political majority decision making, and this appears as an outright violation of the principle. It was already remarked by philosopher Jean-Jacques Rousseau that majority decision making presupposes the existence of at least one preceding unanimous decision, namely the decision to take future decisions with majority rule. ${ }^{26}$ With regard to the vast majority of scientific and technological developments and applications, it is totally spurious to assume such preceding unanimous decision.

This apparent inconsistency between ethical principle and actual practice is the more serious, because the legal liability for the negative effects of such nonunanimous decisions is often conditional, partial, or even completely lacking (Zandvoort 2011). Hence the right to reparation or compensation mentioned above is not, or is only partially, safeguarded. This is not merely unjust, it also threatens the sustainable and responsible exploitation and application of science and technology. For if actors are not held responsible, in the sense of liable for the harm that their activities may cause to others, then it cannot be expected that they will sufficiently weigh the social costs of their activities into their decisions.

2. Freedom of speech is often considered an almost inviolable human right. One would think that it is also an indispensable principle for science and engineering ethics. Indeed, many codes of ethics for engineers seem to impose upon engineers a duty to inform the public about the (possible) consequences of their work. ${ }^{27}$ Yet, if one is an employee in a private or public hierarchical

\footnotetext{
25 "No engineers have seriously considered whether or not they have a responsibility similar to that of physicians, scientific researchers, and other professionals to obtain the informed consent of parties to be affected by their actions before embarking on those actions, although it appears prima facie that there is no reason why engineers should not bear this as a responsibility associated with their professional practice." (Baum 1980, p. 68)

"Viewing engineering as an experiment on a societal scale places the focus where it should be: on the human beings affected by technology; for the experiment is performed on persons, not on inanimate objects. In this respect, albeit on a much larger scale, engineering closely parallels medical testing of new drugs and techniques on human subjects. [...] While current medical practice has increasingly tended to accept as fundamental the subject's moral and legal rights to give informed consent before participating in an experiment, contemporary engineering practice is only beginning to recognize those rights. We believe that the problem of informed consent, which is so vital to the concept of a properly conducted experiment involving human subjects, should be the keystone in the interaction between engineers and the public" (Martin and Schinzinger 1996, pp. 84-5).

26 “...unless the king has been elected by unanimous vote, what, failing a prior agreement, is the source of the minority's obligation to submit to the choice of the majority? Whence the right of the hundred who do wish a master to speak for the ten who do not? The majority principle is itself a product of agreement, and presupposes unanimity on at least one occasion." (Quoted from Mueller 2003, p 128).

27 Engineering Council UK, Guidance on Risk: Engineers should [...] "be prepared to engage in public debate on the perceived risks and benefits". http://www.engc.org.uk/about-us/guidance-on-risk\# (Accessed 5 November 2013).
} 
organisation, such as a business organisation or a governmental organisation, then one's freedom to speak is drastically curtailed. ${ }^{28}$ Most professionals, including most scientists and engineers, are such employees. In those organisations, a separation of powers similar to the separation of governmental powers does not exist. ${ }^{29}$ If, for instance, an employee brings forward to a confidant within the organisation an alleged case of abuse or misconduct in that organisation, often the case will ultimately be judged by the very person who, as an executive, is responsible for the contested situation or conduct. (It should be noted that the confidant is also an employee of the organisation hence is subjected to the same powers.) Such a conflation of executive and judicial powers within a hierarchical organisation is in striking contrast with the situation outside such organisations, where in democratic countries, such powers have long since been separated. If an employee does not acquiesce in the decisions of his superiors and decides to make public the allegation of misconduct and thereby becomes a whistle blower, then his action is often met with a disproportionate response, as recent cases of whistle blowers have confirmed. ${ }^{30}$

\section{Footnote 27 continued}

NSPE Code of Ethics of Engineers, Fundamental Canon 3: "Engineers shall issue public statements only in an objective and truthful manner." http://www.nspe.org/Ethics/CodeofEthics/index.html (Accessed 5 November 2013).

IEEE Code of Ethics: "We, the members of the IEEE, [...] agree [...] to disclose promptly factors that might endanger the public or the environment". http://www.ieee.org/about/corporate/governance/p7-8. html (Accessed 5 November 2013).

IEEE does not say to whom engineers should disclose factors etc. ASME is more clear by stating in its Criteria for Interpretation of the Canons that "Whenever the Engineers' professional judgments are over ruled under circumstances where the safety, health, and welfare of the public are endangered, the Engineers shall inform their clients and/or employers (and no others, HZ) of the possible consequences." https://www.asme.org/about-asme/get-involved/advocacy-government-relations/ethics-in-engineering (Accessed 5 November 2013).

${ }^{28}$ The following was written 35 years ago about the USA: "For nearly two centuries Americans have enjoyed freedom of press, speech, and assembly, due process of law, privacy, freedom of conscience, and other important rights - in their homes, churches, political forums, and social and cultural life. But Americans have not enjoyed these civil liberties in most companies, government agencies, and other organizations where they work." (Ewing 1977, p. 3) "In effect, therefore, US society is a paradox. The Constitution and Bill of Rights light up the sky over political campaigners, legislators, civic leaders, families, church people, and artists. But not so over employees. The employee sector of our civil liberties universe is more like a black hole, with rights so compacted, so imploded by the gravitational forces of the legal tradition, that, like the giant black stars in the physical universe, light can scarcely escape." (Ewing 1977, p. 5) Since this was written, there have been certain changes regarding hierarchical organisations, both in the USA and in Europe. Some organisations have installed internal, confidential ombudsmen. In some cases they have adopted explicit policies for whistle blowers. In some countries legislation has been adopted aimed at protecting whistle blowers. But as the persistent problems with, and experienced by, whistle blowers reveal, the issue of the limited freedom of speech of employees of public and private organisations has not been resolved, and therefore deserves the attention of all citizens, including scientists and engineers.

${ }^{29}$ The powers of modern governments are divided among the legislative branch (the parliament), the executive branch (e.g. the president), and the judiciary branch (the courts).

${ }^{30}$ For some additional examples and discussion of Dutch/European whistle blowers see the work of Zandvoort and colleagues (2000a). Many other cases could be added. 
These examples of ethical analyses illustrate the problematic organisational, legal and political context in which science and technology function, and in which scientists and engineers do their work. This broader context has a decisive influence on how the work of scientists and engineers is used in society. In order to empower future scientists and engineers for socially responsible decision making and action, they need to be able to similarly assess the organisational, legal and political context in which they work, in order to identify problems and to contribute to their solutions.

Contributions to this special issue present examples of teaching and learning activities (courses, workshops, projects and other forms of active learning methods) that aim at developing such competencies among science and engineering students. Doorn and Kroesen (2011) provide an example of how competence in social responsibility can be clarified and developed through the use of role plays. They show that role plays can enhance a student's ability to identify ethical dilemmas, make sound ethical judgments, and evaluate how the social, legal, and institutional frameworks could be improved. While the teaching activities described in this issue may not be the best possible or even sufficient in view of what is needed for preparing students in science and engineering for social responsibility, we do believe that they exemplify what is currently maximally happening and possible in this regard.

\section{Bottom-Up and Top-Down Processes}

A recurring theme within the network from which the present special issue has evolved is that education for social responsibility is too dependent on the "bottomup" initiatives of isolated individuals or groups at universities. It is often felt that "top-down" support from the university organisation in the form of staff, financing and curriculum time is inadequate, and that relevant educational mechanisms, structures and policies are ineffective or not sufficiently effective to secure incorporation of appropriate education for social responsibility in teaching programmes. Examples where inadequacies and deficiencies are felt include:

- Educational policies such as "Bologna" and policies at the level of the university;

- (Inter)national criteria and mechanisms for evaluating educational programmes, such as accreditation criteria and mechanisms (Conlon 2013);

- Academic organisational structures (Liebert 2013; Fabregat 2013) and financing (Ozaktas 2011; Spitzer 2013);

- Criteria and mechanisms for academic prestige and career advancement.

As a consequence, far too much depends on the bottom-up initiatives of motivated, but relatively isolated academic individuals or groups, who often experience insufficient support from the top. Those who engage in bottom-up endeavours to set up teaching activities aimed at developing competence in social responsibility in (future) scientists and engineers are often motivated by the desire to change the culture of science and engineering so that it will include ethical 
reflection as an intrinsic element. Sociologist Hans Gullestrup identifies culture as "... the philosophy of life, the values, norms and rules, and actual behaviour-as well as the material and immaterial products from these-which are taken over by man from the past generations, and which man wants to bring forward to the next generation-eventually in a different form-and which in one way or another separate individuals belonging to the culture from individuals belonging to other cultures" (Gullestrup 2003/2004). In this context, changing the culture of science and technology would mean that their core elements (philosophy underpinnings, values, norms and rules, and actual practices) that are transferred in university teaching to the next generation of scientists and engineers are revised so that they include concerns for the environment, public health, peace keeping, and other societal and cultural impacts, as well as ethical reflections on these aspects.

Individuals or groups can act as agents of cultural change by setting up innovative activities (bottom-up) and by acting as role models (Alpay 2011; Baier 2013; Børsen et al. 2013; Fabregat 2013; Liebert 2013; Ozaktas 2011; Spitzer 2013). In some cases, these bottom-up initiatives are embedded in university policies that promote cross-disciplinary or interdisciplinary teaching and learning. At the Technical University of Darmstadt, for example, teachers could get financial support from the university management for the extra costs of interdisciplinary team-teaching, tutoring of small student groups, or the development of active forms of teaching and learning such as project work and role playing (Deneke 2008).

The module "Science bears responsibility" is one part of a successful top-down initiative at Leuphana University Lüneburg (Michelsen 2013). In 2006, after its merger with the University of Applied Sciences Leuphana had new leadership and the ongoing process of reorientation involved "substantial changes to the organisational structure, study programmes and teaching, and campus development, while also maintaining strong ties to the region and, at the same time, developing an international orientation" (Michelsen 2013). Leuphana University Lüneburg considers itself a university for the civil society in the twenty first century and bases its development on a comprehensive concept of education. Education for a sustainable development is understood as a challenge for undergraduate students. Another example of a university-wide initiative is the decision by Delft University of Technology in the 1990s to introduce compulsory courses on ethics and engineering in the engineering curriculum (Scheurwater and Doorman 2001; Van de Poel et al. 2001).

Denmark provides an example on a national level of how a structural push can drive the inclusion of new study modules in university education. In 2000 the Danish Rectors' Conference and the Minister of Education agreed that in all bachelor's programmes at Danish Universities a compulsory study module should be included requiring students to bring their expertise to a higher level by seeing it in a bigger and more general perspective. When the Danish university legislation was changed in 2003, it explicitly stated that all bachelor's study programmes offered at Danish universities must include such a module (LAW No. 403 2003). ${ }^{31}$ Børsen (2008) gives an example of how such a course for science students at the University of Copenhagen was designed and organised.

\footnotetext{
31 https://www.retsinformation.dk/Forms/R0710.aspx?id=29143 (Accessed 5 November 2013).
} 


\section{Priorities for the Future: Course Contents and Alliances with External Partners}

The research and teaching community in which this special issue is rooted could, in the next several years, focus on two important aspects of education for social responsibility: (1) the identification of necessary or desirable teaching contents and (2) establishing alliances with external partners.

Within the network an emphasis has been on teaching and learning methods such as role playing, case study discussions, etc. Valuable as that has been, it is now reasonable to consider more systematically the question of which knowledge, analytical skills, competencies, etc. should be transferred or imparted. If it is possible to identify pertinent knowledge and skills that are required for social responsibility, then this could also help to convince others of the importance of this teaching.

With regard to alliances, there exists a clear opportunity to strengthen existing connections and to establish fruitful new ones with relevant academic societies, accreditation agencies, entities that support corporate social responsibility activities, national unions of scientists and engineers and other related groups (such as science writers, technicians, teachers, etc.) and international organisations of such unions, as well as international structures that facilitate the implementation of international treaties (e.g., the International Nuclear Security Education Network under the auspices of the International Atomic Energy Agency, the Associate Program under the Organisation for the Prohibition of Chemical Weapons, and the Preparatory Committee for the Comprehensive Nuclear-Test-Ban Treaty's Capacity Building Initiative and the Biological Weapons' Convention network).

Culture does not exist independently of human activity nor is culture the product of human activity. The process whereby assumptions, values, norms, rules, and actual behaviour are acquired and maintained can be referred to as socialisation. The reproduction and/or transformation of these elements are the (often unconsciously achieved) product of a variety of activities of which formal education constitutes a subset.

Educational activities that support the formation of cultural traits that focus on social responsibility need to be normalised in the sense that they become integral to the teaching of science and engineering. Individuals who, through their own initiative, develop and implement such activities should be recognized and rewarded. It is a task of university administrators and a responsibility of politicians to ensure that educational programmes that emphasize social responsibility are encouraged and facilitated and, eventually, integrated into the curriculum. This normalisation would include financial support for staff and curriculum time; promoting those programmes and, if necessary, harmonising educational goals to incorporate them into standard teaching (Ethics Across the Curriculum); linking such programmes to accreditation (as ABET has done) and to funding. ${ }^{32}$

\footnotetext{
32 As an example, the US Congress has added to the mission of the National Science Foundation (NSF; a primary funder of scientific research) the requirement that institutions that receive NSF funding must provide trainees with education in the responsible conduct of research.
} 
Normalisation of activities aimed at cultural change will only happen if that cultural change solves a problem. A problem for whom, one can ask? Proponents of changing the culture of science, technology and engineering need to liaise with public, private, and non-governmental stakeholders. Stakeholders range from those who will hire the next generation of scientists, engineers and technical experts, to those who, on a global scale, may be represented by international organisations like the UN, UNESCO, and the World Health Organisation (WHO). Beyond these stakeholders are citizens in general who are stakeholders with a double interest. They experience the overall effects of the work of engineers and scientists and, often, fund their education via the tax system. ${ }^{33}$ Stakeholders in science and technology need to see a shared value in promoting a cultural change that supports social responsibility. It is therefore a challenge to the promoters of education for social responsibility to convince as many stakeholders as possible that this education is, ultimately, in the interest of all.

\section{References}

Adomssent, M., \& Thomas, H. (2013). The concept of competencies in the context of education for sustainable development (ESD). Available at: www.esd-expert.net/assets/130314-Concept-PaperESD-Competencies.pdf.

Alpay, E. (2011). Student-inspired activities for the teaching and learning of engineering ethics. Science and Engineering Ethics, 19(4) this issue. doi:10.1007/s11948-011-9297-8.

Baier, A. (2013). Student-driven courses on the social and ecological responsibilities of engineers. Commentary on "student-inspired activities for the teaching and learning of engineering ethics". Science and Engineering Ethics, 19(4) this issue. doi:10.1007/s11948-013-9490-z.

Baum, R. J. (1980). Ethics and engineering curricula. The teaching of ethics (Vol. VII). Hastings-on Hudson: The Hastings Center.

Bird, S. J. (1993). Teaching ethics in the sciences: Why, how and what. In Ethics, values and the promise of science (pp. 228-232), Research Triangle, North CA: Sigma Xi, The Scientific Research Society.

Bird, S. J. (1994). Overlooked aspects in the education of science professionals: Mentoring, ethics and professional responsibility. Journal Science Education and Technology, 3, 49-55.

Bird, S. J. (1999). Including ethics in graduate education in scientific research. In J. M. Braxton (Ed.), Perspectives on scholarly misconduct in the sciences (pp. 174-188). Columbus: Ohio State University Press.

Bird, S. J., \& Fisher, E. (2011). Science and technology policy in the making: Observation and engagement. Science and Engineering Ethics, 17(4), 607-850.

Børsen, T. (2008). Developing ethics competencies among science students at the University of Copenhagen. European Journal of Engineering Education, 33(2), 177-184.

Børsen, T. (2013). Extended report from working group 5: Social responsibility of scientists at the 59th Pugwash conference on science and world affairs in Berlin, 1-4 July 2011. Science and Engineering Ethics, 19(1), 299-308.

Børsen, T., Antia, A., \& Glessmer, M. (2013). A case study of teaching social responsibility to doctoral students in the climate sciences. Science and Engineering Ethics, 19(4) this issue. doi:10.1007/ s11948-013-9485-9.

Colby, A., \& Sullivan, W. M. (2008). Teaching ethics in undergraduate engineering education. Journal of Engineering Education, 97(3), 327-338.

\footnotetext{
33 For more information and discussion of techniques for recruiting the involvement of a wide-range of stakeholders in education in science, technology and society, both within the academic setting and beyond it, see "Science and Technology Policy in the Making: Observation and Engagement" (Bird and Fisher 2011) a special issue of Science and Engineering Ethics.
} 
Conlon, E. (2013). Broadening engineering education: Bringing the community in commentary on "social responsibility in French engineering education: A historical and sociological analysis". Science and Engineering Ethics, 19(4) this issue. doi:10.1007/s11948-013-9476-x.

Conlon, E., \& Zandvoort, H. (2011). Broadening ethics teaching in engineering: Beyond the individualistic approach. Science and Engineering Ethics, 17(2), 217-232.

De Haan, G. (2010). The development of ESD related competencies in supportive institutional frameworks. International Review of Education, 56(2-3), 315-328.

Deneke, M. (2008). Thirty years of experience with integrating interdisciplinary teaching into engineering and science programs at TU Darmstadt. Available at: www.znf.uni-hamburg.de/presentations9.pdf.

Didier, C., \& Derouet, A. (2011). Social responsibility in French engineering education: A historical and sociological analysis. Science and Engineering Ethics, 19(4) this issue. doi:10.1007/s11948-0119340-9.

Doorn, N., \& Kroesen, O. (2011). Using and developing role plays in teaching aimed at preparing for social responsibility. Science and Engineering Ethics, 19(4) this issue. doi:10.1007/s11948-0119335-6.

Ewing, D. (1977). Freedom inside the organization. New York: Dutton.

Fabregat, J. (2013). Explicit training in human values and social attitudes of future engineers in Spain. Commentary on "preparing to understand and use science in the real world-interdisciplinary study concentrations at the Technical University of Darmstadt”. Science and Engineering Ethics, 19(4) this issue. doi:10.1007/s11948-013-9489-5.

Funtowicz, S., \& Ravetz, J. (1993). Science for the post-normal age. Futures, 25(7), 739-755.

Geerts, R. (2013). Dialogue on sustainable development as part of engineering education: The relevance of the Finnish case. Commentary on "a national collaboration process: Finnish engineering education for the benefit of people and environment". Science and Engineering Ethics, 19(4) this issue. doi:10.1007/s11948-013-9486-8.

Gullestrup, H. (2003/2004). The complexity of intercultural communication in cross-cultural management. Journal of Intercultural Communication, Issue 6, February 2003-May 2004. Available at: www.immi.se/intercultural.

Hackett, E. J. (2002). Four observations about "six domains of research ethics". Science and Engineering Ethics, 8(2), 211-214.

Harris, C. E. (1998). Engineering responsibilities in lesser-developed nations: The welfare requirement. Science and Engineering Ethics, 4(3), 321-331.

Harris, C. E., Davis, M., Pritchard, M. S., \& Rabins, M. J. (1996). Engineering ethics: What? why? how? and when? Journal of Engineering Education, 85, 93-96. doi:10.1002/j.2168-9830.1996.tb00216.x.

Have, T., \& Henk, A. M. J. (2010). UNESCO's activities in ethics. Science and Engineering Ethics, $16(1), 7-15$.

Herkert, J. R. (2000). Engineering ethics education in the USA: Content, pedagogy and curriculum. European Journal of Engineering Education, 25(4), 303-313.

Herkert, J. R. (2005). Ways of thinking about and teaching ethical problem solving: Microethics and macroethics in engineering. Science and Engineering Ethics, 11(3), 373-385.

Honneth, A. (2013). Das Recht der Freiheit-Grundriss einer demokratischen Sittlichkeit. Frankfurt: Suhrkamp Verlag.

Hunger, I. (2013). Some personal notes on role plays as an excellent teaching tool. Commentary on "using and developing role plays in teaching aimed at preparing for social responsibility". Science and Engineering Ethics, 19(4) this issue. doi:10.1007/s11948-013-9477-9.

Kline, R. (2013). Teaching social responsibility for the conduct of research. IEEE Technology and Society Magazine, 2013, 52-58.

Koen, B. V. (2003). On teaching engineering ethics: A challenge to the engineering professoriate. In Proceedings of the 2003 American society for engineering education annual conference \& exposition, 2003. Available at: http://www.ewh.ieee.org/soc/es/koen2.html.

Liebert, W. J. (2013). Preparing to understand and use science in the real world: Interdisciplinary study concentrations at the Technical University of Darmstadt. Science and Engineering Ethics, 19(4) this issue. doi:10.1007/s11948-013-9488-6.

Luhmann, N. (1990). Die Wissenschaft der Gesellschaft. Frankfurt am Main: Suhrkamp.

Martin, M. W., \& Schinzinger, R. (1996). Ethics and engineering (3rd ed.). New York: McGraw-Hill.

May, D. R., \& Luth, M. T. (2013). The effectiveness of ethics education: A quasi-experimental field study. Science and Engineering Ethics, 19(2), 545-568.

Meier-Hüsing, P. (2011). Universität Bremen-40 Jahre in Bewegung. Bremen: Edition Temmen. 
Merton, R. K. (1973). The normative structure of science. In R. K. Merton (Ed.), The sociology of science (pp. 267-278). Chicago, London: The University of Chicago Press.

Michelsen, G. (2013). Sustainable development as a challenge for undergraduate students: The module "science bears responsibility" in the Leuphana Bachelor's Programme. Commentary on "a case study of teaching social responsibility to doctoral students of climate sciences". Science and Engineering Ethics, 19(4) this issue. doi:10.1007/s11948-013-9489-5.

Michelsen, G., \& Adomssent, M. (2007). Education for sustainable development strategies in German universities. In A. E. J. Wals (Ed.), From cosmetic reform to meaningful integration: Implementing education for sustainable Development in Higher Education Institutes-the state of affairs in Six European countries (pp. 21-24). Amsterdam: DHO.

Minehata, M., Sture, J. F., Shinomiya, N., \& Whitby, S. M. (2011). Implementing biosecurity education: Approaches, resources and programmes. Science and Engineering Ethics, 19(4) this issue. doi:10. 1007/s11948-011-9321-z.

Mueller, D. C. (2003). Public choice III. Cambridge: Cambridge University Press.

National Institutes of Health (NIH). (2009). Update on the Requirement for Instruction in the Responsible Conduct of Research. NIH Guide for Grants and Contracts November 24. http:/grants.nih.gov/ grants/guide/notice-files/NOT-OD-10-019.html. Accessed 23 Sept 2013.

Newberry, B. (2010). Katrina: Macro-ethical issues for engineers. Science and Engineering Ethics, 16(3), $535-571$.

Nixdorff, K. (2013). Education for life scientists on the dual-use implications of their research. Commentary on "implementing biosecurity education: Approaches, resources and programmes". Science and Engineering Ethics, 19(4) this issue. doi:10.1007/s11948-013-9478-8.

Ocone, R. (2013). Engineering ethics and accreditation. Education for Chemical Engineers, 8(3), e113e118.

Ozaktas, H. (2011). Teaching science, technology, and society to engineering students: A sixteen year journey. Science and Engineering Ethics, 19(4) this issue. doi:10.1007/s11948-011-9329-4.

Pimple, K. D. (2002). Six domains of research ethics. Science and Engineering Ethics, 8(2), 191-205.

Rathje, D., Spitzer, H., \& Zandvoort, H. (2008). How to prepare students for a responsible use of science and engineering. Results from the workshop "teaching ethics and peace to science and engineering students", University of Hamburg, 15-17 October 2008. Available at: http://www.znf.uni-hamburg. de/brochure.pdf.

Rogers, M. D. (2003). The European commission's white paper "strategy for a future chemicals policy": A review. Risk Analysis, 23(2), 381-388.

Scheurwater, G. J., \& Doorman, S. J. (2001). Introducing ethics and engineering: The case of Delft University of Technology. Science and Engineering Ethics, 7(2), 261-266.

Schlossberger, C. E. (1997). The responsibility of engineers, appropriate technology, and lesserdeveloped nations. Science and Engineering Ethics, 3(3), 317-326.

Shuman, L. J., Besterfield-Sacre, M., \& McGourty, J. (2005). The ABET professional skills-Can they be taught? Can they be assessed? Journal of Engineering Education, 94(1), 41-56.

Slaughter, S. (2002). Commentary on "six domains of research ethics". Science and Engineering Ethics, $8(2), 219-222$.

Sloan, D. (1978). The teaching of ethics in the American undergraduate curriculum, 1876-1976. The Hastings Center Report, 9(6) (December 1978), 21-41.

Spitzer, H. (2013). Introduction of interdisciplinary teaching: Two case studies. Commentary on "teaching science, technology, and society to engineering students: A sixteen year journey". Science and Engineering Ethics, 19(4) this issue. doi:10.1007/s11948-013-9475-y.

Stephan, K. D. (1999). A survey of ethics-related instruction in US engineering programs. Journal of Engineering Education, 88(3), 459-464.

Stichweh, R. (1984). Zur Entstehung des modernen Systems wissenschaftlicher Disziplinen. Frankfurt am Main: Suhrkamp.

Sture, J. (Ed.). (in Press). Yearbook of biosecurity education 2012. Bradford: Bradford University. (ISBN: 978-1-85143-271-4).

Takala, A. J., \& Korhonen-Yrjänheikki, K. (2011). A national collaboration process: Finnish engineering education for the benefit of people and environment. Science and Engineering Ethics, 19(4) this issue. doi:10.1007/s11948-011-9330-y.

The Finnish Higher Education Evaluation Council FINHEEC. (2012). Evaluation of the Bologna process implementation in Finland. Available at: http://www.finheec.fi/files/1471/KKA612Evaluation_ Bologna_nettiin.pdf. 
Van de Poel, I. R., Zandvoort, H., \& Brumsen, M. (2001). Ethics and engineering courses at Delft University of Technology: Contents, educational setup and experiences. Science and Engineering Ethics, 7(2), 267-282.

Weil, V. (2002). Making sense of scientists' responsibilities at the interface of science and society. Science and Engineering Ethics, 8(2), 223-227.

Weingart, P. (2010). A short history of knowledge formations. In R. Frodeman, J. Thompson Klein, C. Mitcham, \& J. Britt Holbrook (Eds.), The Oxford handbook of interdisciplinarity, Chap. 1. Oxford: Oxford University Press.

Wiek, A., Withycombe, L., \& Redman, C. I. (2011). Key competencies in sustainability: A reference framework for academic program development. Sustainable Science, 6(2), 203-218. Published online: 19 May 2011. doi:10.1007/s11625-011-0132-6.

Zandvoort, H. (2005). Good engineers need good laws. European Journal of Engineering Education, $30(1), 21-36$.

Zandvoort, H. (2008a). Preparing engineers for social responsibility. European Journal of Engineering Education, 33(2), 133-140.

Zandvoort, H. (Ed.). (2008b). Preparing engineers for social responsibility. European Journal of Engineering Education, 33(2), Part 1, 133-195.

Zandvoort, H. (2011). Evaluation of legal liability for technological risks in view of requirements for peaceful coexistence and progress. Risk Analysis, 31(6), 969-983.

Zandvoort, H., Van de Poel, I., \& Brumsen, M. (2000a). Ethics in the engineering curricula: Topics, trends and challenges for the future. European Journal of Engineering Education, 25(4), 291-302.

Zandvoort, H., Van de Poel, I., \& Brumsen, M. (Ed.). (2000b). Ethics in engineering education. European Journal of Engineering Education, 25(4), 291-338.

Zandvoort, H., Van Hasselt, G. J., \& Bonnet, J. A. B. A. F. (2008). A joint venture model for teaching required courses in 'ethics and engineering' to engineering students. European Journal of Engineering Education, 33(2), 187-195. 